\title{
The Tash her Father Wore: \\ World Literature, Joyce, Kafka and the Invisible \\ in Kemal Kurt's Ja, sagt Molly
}

\author{
Moray McGowan
}

\begin{abstract}
This article studies the Turkish-German writer Kemal Kurt's Ja, sagt Molly (1998) ['Yes, says Molly'], an ironic meta-fiction to which little critical attention has been paid. Kurt questions the representation of Turks as untutored aspirants to Western culture and challenges the traditional images of exclusion and discrimination. Through a study of his use of pastiche and references to World Literature, in particular to Joyce's Ulysses (1922), this article demonstrates the importance of Kurt as a commentator on the ambiguous place of Turkey in Europe and of Turkish-Germans in German culture.
\end{abstract}

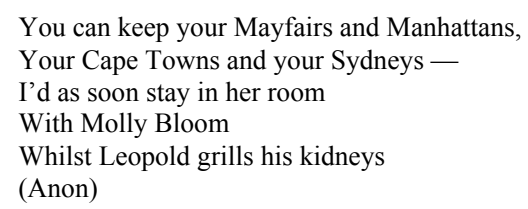

Recent reception of Turkish-German writing, especially in the Englishspeaking world, has rightly underlined how much of this writing shares a resistance towards sociological readings, a questioning and refusal of representation. ${ }^{1}$ This writing does not deny the material realities of migrant experience, but implicitly or explicitly refuses to perpetuate them textually. This, it is pointed out, is a response to a persistent tradition of reception,

${ }^{1}$ Leslie Adelson has forcefully argued this point in a series of important engagements with Turkish-German writing and its reception, culminating in The Turkish Turn in Contemporary German Literature. Toward a New Critical Grammar of Migration (New York: Palgrave MacMillan, 2005); see also (amongst others) Tom Cheesman, 'Juggling Burdens of Representation: Black, Red, Gold and Turquoise', German Life and Letters, 59 (2006), 471-87; Moray McGowan, 'Turkish-German Fiction Since the Mid-1990s', in Contemporary German Fiction, ed. by Stuart Taberner (Cambridge: Cambridge University Press, 2007), pp.196-214. 
particularly in Germany itself, which has for long seemed only able to recognise collective biographies, the migrant labourer in the Turk, the unsophisticated narrative of migrant experience in the text by a writer with a Turkish name. There is an implicit, sometimes explicit assumption that this writing does not participate of or in the literary tradition to which the German critic belongs.

As Leslie Adelson argues, much of the more innovative Turkish-German writing develops 'a persona of migration as historical formation, not of ethnicity as anthropological inscription'. ${ }^{2}$ That is, figures in literary texts who are designated as 'Turkish' are not necessarily ethnic let alone ethnicised characters; they are, indeed, figures, literary tropes, points of view, subject positions from which to engage with German, Turkish, Turkish-German, European and other narratives, histories and memory cultures. Moreover, these texts often play games with the expectations and self-images of their educated German readership, Emine Sevgi Özdamar's pseudo-naïve firstperson narrators with their apparently imperfect grasp of German being perhaps the best-known example. ${ }^{3}$ Even Feridun Zaimoglu's apparently documentary Kanak Sprak: 24 Mißtöne vom Rande der Gesellschaft (1995) ['Spik Speak: 24 Dissonances from the Margins of Society'] is a composition, a soundscape of voices, not a sociological record. The formally most radical of these writers, Zafer Şenocak, cuts the disorientating experiences of migration free from their sociological anchor altogether, creating sometimes labyrinthine, counter-hermeneutical texts which celebrate their own fictionality. ${ }^{4}$

Whilst Şenocak remains woefully underrecognised in Germany, he has at least begun to enjoy an international reception. ${ }^{5}$ Kemal Kurt's ironic metafiction, Ja, sagt Molly (1998) ['Yes, says Molly'], an equally insistent

\footnotetext{
${ }^{2}$ Adelson, The Turkish Turn, p.169.

${ }^{3}$ For example in Mutter Zunge (1990) ['Mother Tongue'], Das Leben ist eine Karawanserai (1993) ['Life is a Caravanserai'], or Seltsame Sterne starren zur Erde (2003) ['Strange Stars Look Down to Earth'].

${ }^{4}$ For example his sequence of fictions Der Mann im Unterhemd (1995) ['The Man in the Vest'], Die Prärie (1997) ['The Prairie'], Gefährliche Verwandtschaft (1998) ['Dangerous Relationship'], and Der Erottomane (1999) ['The Erotomaniac'].

${ }^{5}$ See, for example, Zafer Şenocak, ed. by Tom Cheesman and Karin Yeşilada (Cardiff: University of Wales Press, 2003).
} 
antidote to reading Turkish-German writing as literal representation, is by contrast already almost forgotten. ${ }^{6}$ Kemal Kurt (1947-2002) was born and grew up in Çorlu in the 3\% of modern Turkey that lies west of Istanbul and is part of Europe. He was educated in Switzerland and the United States, held an engineering doctorate from the Technische Universität Berlin and was a photographer, translator and author of children's books and radio plays. His essay Was ist die Mehrzahl von Heimat? Bilder eines türkisch-deutschen Doppellebens (1995) ['What is the Plural of "Homeland"?: Pictures from a Turkish-German Double Life'] $]^{7}$ explores the contradictions encapsulated in his title: for of course the German word 'Heimat' does not have, and thus does not permit, a plural, and the Federal Republic long resisted the concept of dual nationality. These contradictions exist both within Kemal Kurt's own sense of self and within German and European culture, orientalist projections that exclude him, as a Turk, from the Europe in which he in fact grew up.

This critique of exclusion resonates in Kurt's Ja, sagt Molly, which even though it is not obviously a text of Turkish-German or migrant experience at all, subtly embeds this experience in an imaginative panorama of modernity and its self-inflicted catastrophes, that plays out in a composite and implicitly cosmopolitan city that could be 'London [...], Paris oder Berlin. Oder auch New York, Tokio, Dublin, Istanbul, Toronto, Kalkutta, Kinshasa, Ulan Bator, Samarkand, Astrachan'. ${ }^{8}$ The novel has three partly intercut, partly interwoven strands.

Firstly, short headlines summarise the century's political and scientific milestones and its natural and man-made catastrophes, from the Boxer Rebellion to the collapse of communism, El Niño or the Balkan genocides of

${ }^{6}$ Almost the only critical engagement with this novel apart from reviews is to be found in Tom Cheesman, Novels of Turkish German Settlement: Cosmopolite Fictions (Rochester: Camden House, 2007), pp.54-57 and 117-22: an excellent analysis which emphasises important elements of the novel that cannot be discussed here, such as its tension between 'Joycean affirmation of transcultural fecundity' and 'Kafkaesque anguish over internalized inhumanity and consequent ethnic, national, religious, interpersonal and psychic violence' (p.55). I draw extensively on Cheesman here, but in order to develop a facet of the novel which Cheesman does not address at all. Translations of titles unpublished in English are my own.

${ }^{7}$ Reinbek: Rowohlt, 1995.

${ }^{8}$ Kemal Kurt, Ja, sagt Molly (Berlin: Hitit, 1998), pp.9-10. Future references are given by page number in the text; translations are mine. 
the 1990s. Accompanying this strand of references to empirical human history are the second and third strands, two interwoven literary plots. In one, the unidentified narrator, prompted by Jorge Luis Borges's story 'The Library of Babel' (1941), tries to imagine the twentieth century's book of all books. Borges's story posits an infinite library, containing every possible book, so that it is enough to imagine a book, and it will be in the library, as will, indeed, the inconceivably vast number of books that differ from that book by as little as one letter or punctuation mark, and so on. 'The Library of Babel' thus contains, for example, the book that explains the origins of the universe, or the meaning of life, or all other books in the library, as well as vast numbers of books that fall imperceptibly short of providing this explanation, and much, much vaster numbers that make no sense whatsoever.

This celebration of the infinite possibilities and simultaneously infinite absurdities of the logos is the ironic backdrop against which, in Kurt's Ja, sagt Molly, some 160 protagonists from twentieth-century world literature fight desperately for survival. For unlike the infinite library in Borges's parable, their library is overflowing and, it has been decided, must be purged of all but one work, and thus of all but one fictional protagonist. Between bemoaning the marginalisation and trivialisation of literature by the publishing industry and corrupted popular taste on the one hand, and the unreadability of much modernist literature on the other, the protagonists slaughter each other in would-be self-preservation. Those that are left over form a mob that storms and burns the library itself, rendering their own and only habitation uninhabitable, echoing the self-destructive paroxysms that periodically gripped twentieth-century humanity. ${ }^{9}$

Kurt's implied reader recognises not only Proust's Swann, Mann's Leverkühn or Hasek's Schwejk, but also much less familiar figures, say from Hubert Selby's Last Exit to Brooklyn or Witold Gombrowicz's Ferdydurke. Few real readers would be able to dispense with the novel's glossary, as Ja, sagt Molly ranges across twentieth-century West and East European, North

${ }^{9}$ The mob is led by Julia Jurenito, anti-hero of Ilya Ehrenburg's novel The Extraordinary Adventures of Julia Jurenito and his Disciples (written in Belgium in 1922; first published 1930); Ehrenburg, a Ukrainian Jewish writer in Russia, co-author of a 'Black Book' chronicling the Nazi murder of Soviet Jews, was an emphatic cosmopolitan by conviction and experience but also author of extreme anti-German hate propaganda (see Cheesman, Novels of Turkish German Settlement, p.57). 
and South American, Arabic, Asian and African literature from at least twenty languages. There is over-compensation in this cosmopolitanism, perhaps; certainly the novel can be read as a riposte to the patronising attitude of German interviewers and critics towards Turkish-German writers as supposedly untutored aspirants to Western culture. Even the most widely and eclectically read Western reader is likely to have to acknowledge the combination of Eurocentricity and Atlanticist bias in what they know and have read. ${ }^{10}$ Moreover, Kurt does not merely invoke world literature through its heroes and heroines; he also moves elegantly from one brief pastiche to another, be it of Samuel Beckett, Albert Camus or Agatha Christie.

At the novel's mid-point, a group of minority protagonists from the works of Joseph Conrad, Kazuo Ishiguro, Tahar Ben Jelloun, Hanif Kureishi, Michael Ondaatje, Jean Rhys or Salman Rushdie gather in the house of V.S. Naipaul's fictional Mr Biswas to celebrate the impact of the recently emerged 'fünfte Literatur' (literature of migration not only as a challenge to the conventional four points of the compass, ${ }^{11}$ but also as a 'fifth column' that subverts the canon from within). Mingling amongst this group of by now relatively familiar - to the Western reader - minority protagonists, is Ali Itır, the central figure in Turkish-German author Aras Ören's Bitte, nichts Polizei (1981) ['Please, no police'], whose re-emergence from the dead in Ören's more self-reflexively fictional novel Berlin Savignyplatz (1995) emphasises his status as a fiction, a trope of minority and migrant experience. ${ }^{12}$ Kemal Kurt seems here to imply that Ören, one of the most important Turkish-German writers of the 1980s but now largely ignored, belongs alongside these other now internationally known writers of migration and post-colonialism. As the group plots the promotion of this 'fünfte

${ }^{10}$ Tom Cheesman rightly points out that Kurt's novel itself also reflects this same Eurocentric and Atlanticist bias to some extent; almost half the protagonists are from Anglophone literature (Cheesman, Novels of Turkish German Settlement, p.55). But the fact that it does so only emphasises how severe this bias is in most Western conceptual maps of world literature.

${ }^{11}$ See Cheesman, Novels of Turkish German Settlement, p.54.

${ }^{12}$ See, for example, Irmgard Ackermann, 'Ali Itır's Wandlungen: Aras Örens Romanheld zwischen Wirklichkeit und Phantasie', in Interkulturelle Konfigurationen: Zur deutschsprachigen Erzählliteratur von Autoren nichtdeutscher Herkunft, ed. by Mary Howard (Munich: iudicium, 1997), pp.17-30. 
Literatur', the Oberförster, the Head Forester from Ernst Jünger's Auf den Marmorklippen (1939) suddenly smashes the window with his jackboot, sneers at migrant and minority writing as a 'Bereicherung', an enrichment of German literature (75) - Kemal Kurt's ironic allusion to the colonising embrace of the literature of migration by many German critics - and wipes them all out with a molotov cocktail. The reference to racist arson attacks on members of minorities in 1990s Germany is indirect but unmistakeable, as is the implication of literature's helplessness against naked aggression.

However, the novel also offers at least textual defiance on the part of what Deleuze and Guattari called 'minor literature', literature written in a major language from a minor or marginal position..$^{13}$ At the same time, the clues that the text leaves serve to unsettle the uncritical privileging of minority positions too. For while the century takes its course and the other protagonists die in dozens, the third strand of the novel charts the sexual arousal of Joyce's Molly Bloom by Kafka's Gregor Samsa, pairing 'the allaffirming epitome of sexually active femininity' with 'the icon of male alienation and abjection'. ${ }^{14}$ The novel's title alludes to the 'Yes' with which Molly's famous affirmation of her sexuality, the monologue that forms the closing forty-five pages of Joyce's novel, begins and ends. Metamorphosed from human into 'Ungeziefer' ['vermin'] as in Kafka's story, but shrunk to the less alarming size of an actual insect, Gregor delicately wanders Molly's body. When at the novel's end Gregor bids Molly adieu and disappears into a fissure in the wall, the future is at best uncertain. After all, the sky is apocalyptically aflame and a scorched book page is fluttering past. But Gregor and Molly are the only protagonists to survive even this far. Moreover, the struggles of the 160 protagonists from World Literature are in fact embedded in the frame narrative of Molly's dream; almost from the outset we read that she will 'alles vom Bett aus erleben' (13) ['experience everything from her bed.']

Gregor's diminutive size in Kemal Kurt's rewriting of the metamorphosis fable, and 'his essentially servile role as a worker', ${ }^{15}$ reflect both a general

\footnotetext{
${ }^{13}$ Gilles Deleuze and Felix Guattari, Kafka: Towards a Minor Literature (Minneapolis: University of Minneapolis Press, 1986).

${ }^{14}$ Cheesman, Novels of Turkish German Settlement, p.120.

${ }^{15}$ Cheesman, Novels of Turkish German Settlement, p.121.
} 
crisis of male identity in late modernity and the acute form of this crisis in the experience of male migrants, particularly migrant labourers. ${ }^{16}$ Moreover, Gregor Samsa, the creation of a Czech Jew writing in German, is the most famous fictional personage in 'minor literature', as well as the century's most famous example of literature's capacity to unsettle by refusing resolution: What is this creature? (Though Kafka does it, of course, not by blurring two incompatibles, but by forcing them to occupy, impossibly, the same narrative space, the same textual body). This question, which Gregor's transformation imposes on his family, and Kafka's text imposes on his readers, whilst frustrating all attempts at an unambiguous answer, resembles that which troubles settled cultures faced with figures of migrant and therefore unresolved form. Or at least used to trouble them until, in the realm of cultural discourse if not of empirical experience, hybrid, cross- and multicultural identities gained a fashionable cachet. For the contemporary reader, Molly Bloom invites identification by embodying multiple minority or otherwise transgressive roles, as a woman whose sexual self-affirmation challenges the view of women dominant in her times, as a woman with, at least in Leopold Bloom's imaginings, the 'blood of the south. Moorish, ${ }^{17}$ as the inhabitant of a small, dominated country on the periphery of Europe, and married to Leopold Bloom, himself Jewish and the son of an archetypal migrant.

Within this more general alignment of Molly with other marginal identities in twentieth-century Europe, Kemal Kurt's novel establishes an indirect yet unmistakeable parallel between, on the one hand, Ireland's sometime peripheral status in the shadow of its powerful, often patronising neighbour, despite a proud and ancient history of contribution to Europe's heritage, and on the other hand the marginalisation and exclusion of Turkey from the Western-dominated self-definition of Europe, despite its formative contribution to European culture at numerous points in the latter's history. (Writing in the mid-1990s, Kemal Kurt could not have known of the boom

\footnotetext{
${ }^{16}$ On migrant masculinities and their exploration in Turkish-German writing, see Moray McGowan, 'Multiple Masculinities in Turkish-German Men's Writing', in Conceptions of Postwar German Masculinity, ed. by Roy Jerome (Albany: SUNY, 2001), pp.289-312.

${ }^{17}$ James Joyce, Ulysses (Harmondsworth: Penguin, 1969), p.371; first published in 1922 and hereafter quoted as $\mathrm{U}$ followed by page number in the text.
} 
that was about to turn the Irish into a nation of international property investors, the new absentee landlords of Europe, thus substantially qualifying their dearly-held underdog image).

Those readers who really do have the knowledge of the Western modernist canon of which Turkish-German authors are so often assumed to be ignorant and to which Turkish-German culture is so often treated as not belonging, will find in the novel a ghostly Turkish presence, a wry commentary on exclusion. One of the novel's last references to the twentieth century's milestones is to the continued exclusion of Turkey from the enlarged EU agreed in 1997. The Turkish references in Ja, sagt Molly appear at first sight unconnected to the tryst of Joyce's Molly and Kafka's Gregor. But those who have actually read Joyce's Ulysses know that Molly in fact grew up in Gibraltar. Gibraltar was a British military microcosm, one of those outposts of the Empire whose Britishness came to exceed that of the British homeland itself. Yet it is also a place on the very edge of Europe just as, in their different ways, Ireland and Turkey are on the edge of Europe. Furthermore, Gibraltar was also a place where, in Molly's own daydreams that may be based on her actual memories, on a fantasy no less orientalist than Leopold's, or on some combination of the two, the colour, sensuality and variety created by the intermingling of 'the Greeks and the Jews and the Arabs and the devil knows who else from all the ends of Europe': an image which echoes familiar characterisations of Istanbul and shares the latter city's ambiguity in that it positions the periphery as the node of confluence (U 704).

Molly's father, Major Brian Cooper Tweedy, from his surname to his service with the Royal Dublin Fusiliers at Rorke's Drift (U 442; a battle whose role as a foundation myth of the British Empire was restated in the film Zulu, 1964), embodies and exemplifies Britishness. Bloom implies, too, that Brian Tweedy also fought at Plevna (now Pleven, in Bulgaria) during the Russo-Turkish war of 1877-78 (U 58). This is historically very improbable: Britain was in fact neutral during that war, and though there were individual British participants, such as Frederick von Herbert, ${ }^{18}$ neither the Royal

\footnotetext{
${ }^{18}$ Frederick William von Herbert, The Defence of Plevna, 1877 (London and New York: Longmans, 1895); see also Charles Snodgrass Ryan, Under the Red Crescent - Adventures
} 
Dublin Fusiliers nor any other units served there. However, the Turkish defence of the town was widely admired in Western military circles for the design of the fortifications and the tenacity of the troops. Kemal Kurt not only dazzles and chastens his Western readers with a demonstration of their limited literary horizons compared with his panoply of literary figures, but in foregrounding the figure of Molly Bloom also leaves a literary clue for the particularly alert and genuinely well-read. ${ }^{19}$ For in Joyce's Ulysses Major Brian Tweedy not only exudes Britishness, but is also 'moustached like Turko the Terrible' (U 525). The embodiment of Britishness displays, indeed sprouts, for all to see, a marker of otherness, exemplifying the absurdity of concepts of ethnic purity in a world of migration and intermingling. And that marker is an explicit allusion to the presence of Turkey in Western constructions of the Orient.

Though Joyce's Ulysses is of course famously tied to the specific locality of Dublin, its cultural, mythical and literary allusions are linguistically and thematically cosmopolitan. The Orient generally, and Turkish motifs in particular, crop up repeatedly throughout the novel. ${ }^{20}$ Within the first half a dozen pages we have a reference to the pantomime Turko the Terrible, to which we return below. The bulkiest volume in Leopold Bloom's library is a work he has acquired from Brian Tweedy, 'Hozier's History of the Russo-

of an English Surgeon with the Turkish Army at Plevna and Erzeroum 1877-1878 (London: John Murray, 1897).

${ }^{19}$ And, lest this seems like arrogance on my part, I freely acknowledge here that whilst I was aware of the Turkish motif running through Ulysses, I needed the following to be able to explore the allusions more fully: Weldon Thornton, Allusions in Ulysses: An Annotated List (Chapel Hill: University of North Carolina Press 1968); Phillip F. Herring, 'Lotuseaters', in James Joyce's Ulysses: Critical Essays, ed. by Clive Hart and David Hayman (Berkeley: University of California Press, 1977), pp.71-89; Don Gifford and Robert J. Seidman, Ulysses Annotated: Notes for James Joyce's Ulysses (Berkeley: University of California Press, 1988); Henriette Lazaridis Power, 'Pantomime Songs and the Limits of Narrative in Ulysses', in Picking Up Airs: Hearing the Music in Joyce's Text, ed. by Ruth Bauerle (University of Illinois Press, 1993), pp.53-66; Zack R. Bowen, Bloom's Old Sweet Song: Essays on Joyce and Music (Gainesville: University Press of Florida, 1995), especially pp.98-99.

${ }^{20}$ Turko crops up again in Finnegan's Wake, though he is overshadowed there by a more extensive framework of allusion to the Arabian Nights. 
Turkish War' (U 630). In true orientalist fashion, though, ${ }^{21}$ the principal association with the Orient in general and Turkishness in particular, is sensuality. ${ }^{22}$ Leopold Bloom's fantasies often invoke oriental motifs: in the midst of his stream of consciousness, he wanders 'through awned streets. Turbaned faces going by. Dark caves of carpet shops, big man, Turko the terrible, seated crosslegged smoking a coiled pipe. Cries of sellers in the streets. Drink water scented with fennel, sherbet' (U 59). He imagines 'whores in Turkish graveyards' (U 110). He projects himself as a wealthy pasha, or Molly as a voluptuous odalisque. He visits the 'Hammam. Turkish', which reminds him 'of a mosque, redbacked bricks, the minarets' (U 86-7). He fantasises Molly in Turkish slippers or 'Turkey trunks' (U 394, cf. U 378 ), or in voluminous drawers 'redolent of opoponax, jessamine and Muratti's Turkish cigarettes' (U 651). In the 'nighttown' section of Ulysses Bloom sees 'beside a mirage of datepalms a handsome woman in Turkish costume', who turns out to be Molly: 'Opulent curves fill out her scarlet trousers and jacket slashed with gold. A wide yellow cummerbund girdles her. A white yashmak violet in the night, covers her face, leaving free only her large dark eyes and raven hair' (U 431). While a great deal of this is as much vaguely orientalising as specifically Turkish, of course, there is no doubt that Joyce's cultural-historical sweep very much includes Turkey and the Ottoman Empire as well as myths and allusions from classical antiquity and the Judaeo-Christian tradition. Moreover, it is specifically Molly that is associated in Bloom's mind with Turkey and the Orient.

But neither Major Brian Tweedy nor his Turkish tash, nor indeed Molly's oriental traits at least in the fantasies of her husband, are actually mentioned

\footnotetext{
${ }^{21}$ For all his celebrity as a modernist iconoclast, Joyce is seen by at least one commentator as an inevitably orientalist, racist product of his times; see Vincent John Cheng, Joyce, Race and Empire (Cambridge: Cambridge University Press, 1995).

${ }^{22}$ One of Bloom's 'nighttown' fantasies conjures up a landscape where gazelles graze beside cedargroves: 'It burns, the orient, a sky of sapphire, cleft by the bronze flight of eagles. Under it lies the womancity' (U 454). This last figuring of the city as a female body, wandered by the male flaneur, is also arguably echoed in the form of Kurt's novel, where the composite city imagined by the frame narrator gives way to the image of Molly's body being roamed, bestridden and conquered by Gregor Samsa.
} 
in Ja, sagt Molly. ${ }^{23}$ Only those who have not only read Ulysses, but read it attentively and nearly to the end, where this brief reference to Turkish facial hair occurs, will spot the clue. But to those who really know the textual landscape of modern and post-modern Europe, Kurt's Ja, sagt Molly wryly hints that 'the Turk', bristling with signifiers, is already there: plainly visible despite his overlooked invisibility. ${ }^{24} \mathrm{He}$ is visible, of course, not as an active subject in his own right, but as an import, a decorative flourish on the body of the dominant, Western subject. None the less, the Turk was, indeed, there from the start: a handful of pages into Ulysses, Stephen Dedalus remembers that his mother was fond of a song from Turko the Terrible, the popular pantomime by Erwin Hamilton, first performed in Dublin in $1873 .{ }^{25}$ The plot of Turko the Terrible turns partly on the white rose that Turko brandishes, a rose that renders its bearer invisible. Stephen Dedalus recalls, further, that his mother heard an actor called Royce sing in Turko the Terrible and 'laughed with others when he sang: I am the boy/That can enjoy/Invisibility' (U 16).

Since Kemal Kurt died in 2002 (aged only fifty-five), we cannot now establish for sure quite how much of this Turkish theme in Joyce's Ulysses he intended the implied reader of Ja, sagt Molly to recognise. But Ja, sagt Molly arguably has both an implied reader who will fail to spot the reference because he or she has not actually read the modernist canon, and another, implied or aspired-for reader, who has done so, and who will acknowledge for its author a place in European culture that, as a Turkish-German migrant, this author had found his host society unwilling to grant him. Of course, knowingly oblique references of this kind always risk cultural snobbery. Yet the intertextual presence-in-absence of this Turkish motif in Ja, sagt Molly acquires a fascinating political resonance with the ambiguous place of Turkey in Europe and of Turkish-Germans in German culture.

\footnotetext{
${ }^{23}$ In Turkish, 'tash' denotes a stone; but I refer here merely to the English colloquialism for a moustache

${ }^{24}$ Eric Wolf entitled his study of the characteristically unacknowledged contribution of migrant workers to the development of Europe Europe and the People Without History (Berkeley: University of California Press, 1982).

${ }^{25}$ An adaptation to Dublin circumstances of William Brough's Turko the Terrible; or The Fairy Roses, performed in London in 1868.
} 